\title{
Correction to: Acceptance and willingness to pay for COVID-19 vaccine among school teachers in Gondar City, Northwest Ethiopia
}

Kegnie Shitu* ${ }^{*}$, Maereg Wolde, Simegnew Handebo and Ayenew Kassie

\section{Correction to: Trop Med Health (2021) 49:63} https://doi.org/10.1186/s41182-021-00337-9

Following publication of the original article [1], the authors identified errors in the first name of Maereg Wolde and Simegnew Handebo.

The incorrect author names are: Meareg Wolde and Simegniew Handebo.

The correct author names are: Maereg Wolde, Simegnew Handebo.

The author group has been updated above and the original article [1] has been corrected.

\section{Reference}

1. Shitu K, Wolde M, Handebo S, Kassie A. Acceptance and willingness to pay for COVID-19 vaccine among school teachers in Gondar City, Northwest Ethiopia. Trop Med Health. 2021;49:63.

\section{Publisher's Note}

Springer Nature remains neutral with regard to jurisdictional claims in published maps and institutional affiliations. 